\title{
Correction to: Minnesota peat viromes reveal terrestrial and aquatic niche partitioning for local and global viral populations
}

Anneliek M. ter Horst ${ }^{1}$, Christian Santos-Medellín', Jackson W. Sorensen ${ }^{1}$, Laura A. Zinke ${ }^{1}$, Rachel M. Wilson², Eric R. Johnston ${ }^{3}$, Gareth Trubl ${ }^{4}$, Jennifer Pett-Ridge ${ }^{4}$, Steven J. Blazewicz ${ }^{4}$, Paul J. Hanson ${ }^{5}$, Jeffrey P. Chanton ${ }^{2}$, Christopher W. Schadt ${ }^{3}$, Joel E. Kostka ${ }^{6,7}$ and Joanne B. Emerson ${ }^{1,8^{*}}$

Correction to: Microbiome 9, 233 (2021)

https://doi.org/10.1186/s40168-021-01156-0

Following the publication of the original article [1], the co-author reported that his name should be "Gareth Trubl" (no middle initial G) instead of "Gareth G. Trubl".

The original article has been updated to correct this.

\begin{abstract}
Author details
'Department of Plant Pathology, University of California, Davis, CA, USA. ${ }^{2}$ Department of Earth, Ocean, and Atmospheric Science, Florida State University, Tallahassee, FL, USA. ${ }^{3}$ Biosciences Division, Oak Ridge National Laboratory, Oak Ridge, TN, USA. ${ }^{4}$ Physical and Life Sciences Directorate, Lawrence Livermore National Laboratory, Livermore, CA, USA. ${ }^{5}$ Environmental Sciences Division, Oak Ridge National Laboratory, Oak Ridge, TN, USA. ${ }^{6}$ Schools of Biology and Earth \& Atmospheric Sciences, Georgia Institute of Technology, Atlanta, GA, USA. ${ }^{7}$ Center for Microbial Dynamics and Infection, Georgia Institute of Technology, Atlanta, GA 30332, USA. ${ }^{8}$ Genome Center, University of California, Davis, CA, USA.
\end{abstract}

Published online: 15 December 2021

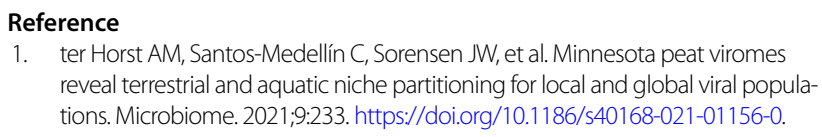

1. ter Horst AM, Santos-Medellín C, Sorensen JW, et al. Minnesota peat viromes reveal terrestrial and aquatic niche partitioning for local and global viral populations. Microbiome. 2021;9:233. https://doi.org/10.1186/s40168-021-01156-0.

The original article can be found online at https://doi.org/10.1186/s40168021-01156-0.

*Correspondence: jbemerson@ucdavis.edu

${ }^{8}$ Genome Center, University of California, Davis, CA, USA

Full list of author information is available at the end of the article

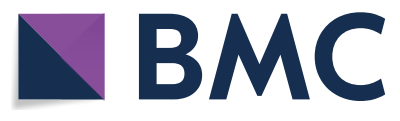

(c) The Author(s) 2021. Open Access This article is licensed under a Creative Commons Attribution 4.0 International License, which permits use, sharing, adaptation, distribution and reproduction in any medium or format, as long as you give appropriate credit to the original author(s) and the source, provide a link to the Creative Commons licence, and indicate if changes were made. The images or other third party material in this article are included in the article's Creative Commons licence, unless indicated otherwise in a credit line to the material. If material is not included in the article's Creative Commons licence and your intended use is not permitted by statutory regulation or exceeds the permitted use, you will need to obtain permission directly from the copyright holder. To view a copy of this licence, visit http://creativecommons.org/licenses/by/4.0/. The Creative Commons Public Domain Dedication waiver (http://creativeco mmons.org/publicdomain/zero/1.0/) applies to the data made available in this article, unless otherwise stated in a credit line to the data. 